УДК 373.2:002.1-028.14:004.65(477):303.7

Букшина Тамара Федотівна

науковий співробітник

Державна науково-педагогічна бібліотека України імені В. О. Сухомлинського, м. Київ, Україна

bukshina@i.ua

\title{
БІБЛІОМЕТРИЧНИЙ АНАЛІЗ НАУКОВИХ ПУБЛІКАЦІЙ 3 ПИТАНЬ ДОШКІЛЬНОЇ ОСВІТИ І ВИХОВАННЯ В ЗАГАЛЬНОДЕРЖАВНІЙ РЕФЕРАТИВНІЙ БД «УКРАЇНІКА НАУКОВА» (1998-2012 рр.)
}

\begin{abstract}
Анотація. Висвітлено результати аналізу потоку наукових публікацій з питань дошкільної освіти і виховання в загальнодержавній реферативній БД «Україніка наукова» за 1998-2012 роки з використанням бібліометричного методу. Означено тенденції розвитку дошкільної освіти і виховання в означеній базі даних. Виявлено реферативну інформацію не тільки щодо найактивніше досліджуваних тем і лакун у цій сфері й інтенсивності їх відображення в окремі роки, а й наукові установи та вищі навчальні заклади, які є лідерами у науковій діяльності з актуальних питань реформування дошкільної освіти і виховання. Наголошено на важливості відображення результатів наукових досліджень у реферативній БД «Україніка наукова».
\end{abstract}

Ключові слова: дошкільна освіта і виховання; загальнодержавна реферативна база даних «Україніка наукова»; бібліометричний аналіз; монографії; автореферати дисертацій; ДНПБ України ім. В. О. Сухомлинського.

\section{1. ВСТУП}

Постановка проблеми. Майбутнє України визначається рівнем освіченості іiі найменших громадян - дітей дошкільного віку. Їхнє морально-духовне становлення, виховання самостійності, формування навичок практичного життя й елементарної соціальної зрілості $\epsilon$ пріоритетними напрямами реформування системи дошкільної освіти - невід'ємної частини оновлення вітчизняної освітньої системи.

Останніми роками набула актуальності особистісно орієнтована модель дошкільної освіти, з'явилося розуміння того, що знання, уміння і навички виступають засобами, а не метою розвитку дитини.

Реалізація прогресивних тенденцій у розвитку дошкільної освіти України пов'язується 3 переосмисленням традиційних функцій педагогічної діяльності, активним запровадженням у практику діяльності дошкільних навчальних закладів рефлексивно-гуманістичної моделі, а саме:

- відмовою від “штампування" пересічної особистості, задавання їй готових нормативів і рецептів для засвоєння й відтворення;

- сприйняттям дошкільного закладу як інституту соціалізації, відповідального за оволодіння дитиною основами “науки життя”;

- зміною орієнтації з діагностики відбору, селекції особистостей за кількісними показниками на користь визначення зони найближчого розвитку кожної дитини;

- створення умов для культивування творчої активності дитини як активного суб' єкта життєдіяльності;

- формування гендерної культури з дитинства.

Важливим $\epsilon$ формування в дошкільника системи ціннісних ставлень до оточуючого світу і самого себе, створення сприятливих умов для реалізації ним 
своїх природних можливостей, сприяння розвитку творчих здібностей й елементарних форм відповідального самовизначення. Ключовими моментами в основі дошкільної освіти виступають: врахування актуальних потреб дітей раннього і дошкільного віку; вироблення оптимістичної гіпотези розвитку кожної дитини; виховання і навчання без примусу й штучного форсування; повага до закономірностей психічного розвитку дошкільника; надання дитині права приймати рішення, а відтак, права на помилку і можливість іiі виправлення; визначення пріоритету повноцінного проживання дитиною дня сьогоднішнього над підготовкою до завтра, далекого майбуття.

За час незалежності Українська держава законодавчо визнала дошкільну освіту обов'язковою первинною складовою системи безперервної освіти, хоча Закон «Про дошкільну освіту» залишається, скоріше, рамковим, оскільки він увесь пронизаний посиланнями на інше законодавство та підзаконні акти [1, с. 124-130].

Важливим кроком для створення передумов успішного розвитку дошкільної освіти стало затвердження Урядом у 2011 році Державної цільової соціальної програми розвитку дошкільної освіти на період до 2017 року. Завдяки скоординованим діям місцевих органів виконавчої влади й органів місцевого самоврядування 31 січня 2010 по 1 січня 2013 року мережа дошкільних навчальних закладів (ДНЗ) збільшилася на 906 одиниць. У тому числі у пристосованих приміщеннях відкрито 868 закладів, уведено в дію 38 новобудов. Відновили свою діяльність 439 ДНЗ, що були в мережі, але тривалий час не функціонували. Додатково у функціонуючих навчальних закладах відкрито 3649 груп для дітей дошкільного віку [11].

Реформування освіти, визначення ії нового змісту, покращення якості навчання можливе лише за умови об'єднання і концентрації зусиль науково-педагогічних працівників Міністерства освіти і науки України (МOH України), Національної академії педагогічних наук України (НАПН України), провідних фахівців у галузі освіти. Таке співробітництво вже знайшло своє відображення в реалізації Національного плану дій, Указів Президента України, постанов Кабінету Міністрів України, державних і галузевих програм, проведення спільних засідань колегій МОH України та Президії НАПН України, тощо. Результатом творчої співпраці МОН України та НАПН України стало затвердження у травні 2012 року нового державного стандарту - Базового компоненту дошкільної освіти.

Президент НАПН України В. Г. Кремень підкреслює, що вчені НАПН України у співпраці 3 МОН України постійно здійснюють науково-методичний супровід трансформацій у освіті, забезпечують виконання основних завдань Національної стратегії, покладених на педагогічну науку. Наголошує, що розпочата модернізація змісту освіти вимагає невідкладного оновлення усіх складових навчально-виховного процесу: методичного забезпечення, створення відповідного освітнього середовища, моніторингу досягнутих результатів, суттєвих змін у педагогічній освіті [7]. Василь Григорович заявляє, що в академії відбувається дослідження розвитку дітей двох i менше років, а 3 порядку денного не знімається питання про створення в НАПН України Інституту дошкільної освіти [6].

Актуальними для дошкільної освіти на найближчу перспективу залишаються питання, пов'язані з підвищенням на державному рівні статусу працівників дошкільної сфери; неухильним виконанням законодавства щодо забезпечення дітям рівного доступу до дошкільної освіти; відновленням функціонування груп для дітей 7-го року життя, які не вступили до школи, а продовжують відвідувати дошкільний заклад; запровадження механізму фінансування педагогічних працівників на придбання науково-методичної літератури для підвищення свого професійного рівня; створення для дітей дошкільного віку іграшок та ігор нового покоління, осучасненням дитячих 
літературних і музичних творів; розробленням варіативної складової змісту дошкільної освіти, що відкриває широкі можливості для створення регіональних і авторських програм; внесення змін у Базові плани підготовки і перепідготовки фахівців за спеціальністю «Дошкільне виховання»; створення підручників і навчальних посібників з дошкільної педагогіки, педагогічної та вікової психології нового покоління [1, с. 130$131]$.

3 огляду на вище викладені проблеми, на МОН України і НАПН України, що здійснюють наукові дослідження в галузі педагогіки, психології, освіти, лягає особлива відповідальність за їхнє розв’ язання.

У цьому контексті підвищується роль одного 3 найвагоміших вітчизняних електронних ресурсів - загальнодержавної реферативної бази даних (РБД) «Україніка наукова» (заснованої у 1998 p. Національною бібліотекою України ім. В. І. Вернадського (НБУВ) спільно з Інститутом проблем реєстрації інформації НАН України (IПРІ НАН України), у якій фіксується реферативна інформація про наукові видання, зокрема, монографії, підручники для ВНЗ, матеріали конференцій, а також автореферати дисертацій та статті з періодичних і продовжуваних видань.

Аналіз останніх досліджень і публікацій. РБД «Україніка наукова»- це не тільки ефективний інструмент пошуку необхідної наукової інформації, а й джерело для оцінки стану науки нашої країни, визначення перспектив розвитку досліджень за напрямом знань, зокрема i 3 питань педагогіки та освіти. Проведені науковцями бібліометричні і наукометричні дослідження РБД «Україніка наукова» і іiї паперового варіанту Українського Реферативного Журналу (УРЖ) «Джерело» дозволяють спрогнозувати тенденції розвитку наукового знання в Україні. Вони допомагають визначити темпи розвитку окремих галузей і пріоритетних напрямів науки.

Про це засвідчив семінар «Бібліометрія та бібліотека: світовий досвід, українська перспектива», проведений у рамках щорічної Міжнародної наукової конференції НБУВ «Адаптація завдань і функцій наукової бібліотеки до вимог розвитку цифрових інформаційних ресурсів», яка відбулася в Києві 8-10 жовтня 2013 р. Зокрема, виступи таких його учасників: як Бережняк О. В. (Рівненський державний гуманітарний університет) [2], Зайченко Н. Я. (НБУВ) [4], Сандул О. Г. (НБУВ) [10] були присвячені відповідно бібліометрії як методу аналізу стану книговидання, бібліометриці у РБД «Україніка наукова», бібліометричному аналізу наукових публікацій 3 проблем розвитку вітчизняної енергетики (на основі реферативних ресурсів НБУВ). Також питанню розкриття ефективності застосування реферативних ресурсів у наукових дослідженнях присвячена публікація Добровської С., Кириленко С., Балагури I. (IПРІ НАН України) [3]. У ній означено тенденції розвитку тематики «Інформаційні технології» в РБД «Україніка наукова», вказано на доцільність планування тематики реферативних видань згідно з даними короткотермінових прогнозів.

У ДНПБ України ім. В. О. Сухомлинського у 2013 році проведено перший бібліометричний аналіз щодо відображення в загальнодержавній РБД «Україніка наукова» наукових видань освітянської тематики. Так, Заліток Л. М. досліджено відображення в РБД документо-інформаційного потоку з питань сухомлиністики. Було визначено перелік типів і видів документів, список авторів, які мають найбільшу кількість публікацій з розглянутої тематики, встановлено коло періодичних видань, у яких представлено документи й матеріали з сухомлиністики, визначено проблеми та шляхи їх розв'язання [3].

Метою статті $є$ висвітлення результатів дослідження щодо тенденцій розвитку педагогічної науки і освіти, зокрема аналізу потоку наукових публікацій з питань дошкільної освіти і виховання в загальнодержавній РБД «Україніка наукова» за 19982012 роки з використанням бібліометричного методу, проведеного в рамках НДР 
«Наукова організація інформаційної діяльності галузевого бібліотечного комплексу Державної науково-педагогічної бібліотеки України імені В. О. Сухомлинського (наук. керівник к. і. н. Воскобойнікова-Гузєва О. В.) (2012-2014 рр.).

\section{2. РЕЗУЛЬТАТИ ДОСЛІДЖЕННЯ}

Об'єктом дослідження було обрано наукові видання, прореферовані в РБД «Україніка наукова», зокрема монографії й автореферати дисертацій, предметом реферати на наукові видання з питань дошкільної освіти і виховання.

Актуальність тематики дослідження полягає у важливості i необхідності ознайомлення вчених-педагогів із станом наукових досліджень 3 питань дошкільної освіти і виховання на сьогоднішньому етапі їхнього реформування через відображення результатів в загальнодержавному реферативному ресурсі.

Під час дослідження (квітень 2013 р.) загальна кількість наукових записів у РБД «Україніка наукова» складала близько 463 тис., зокрема монографій і авторефератів дисертацій - 185,2 тис. (40 \%) від загальної кількості прореферованих публікацій. Розширений пошук видань 3 питань дошкільної освіти і виховання здійснювався за такими пошуковими елементами: кількістю прореферованих записів таких видів видань як книги і автореферати дисертацій у галузі «Культура. Наука. Освіта», роком видання, індексом рубрикатора НБУВ, що відповідає темі дослідження, ключовими словами. УВ РБД «Україніка наукова» знайдено всього 408 документів 3 питань дошкільної освіти і виховання - 0,2 \% від загальної кількості неперіодичних видань.

Статистичний розподіл 408 наукових видань 3 питань дошкільної освіти $\mathrm{i}$ виховання за означеними роками виявив відображення їх найбільшої кількості в РБД за 2008-2012 роки (від 8,1 \% до 11,8 \%) (табл. 1), у той час, коли проводилася підготовка і затвердження Урядом Державної цільової соціальної програми розвитку дошкільної освіти на період до 2017 року (2011 р.), нового державного стандарту - Базового компоненту дошкільної освіти (травень 2012 року). У цей час після дворічної апробації схвалено також програму розвитку дітей старшого дошкільного віку «Впевнений старт», яка $з 1$ вересня 2012 року стала обов'язковою для всіх дошкільних навчальних закладів [4].

Таблиия 1

Динаміка відображення наукових видань 3 питань дошкільної освіти і виховання в РБД «Україніка наукова» за 1998-2012 роки

\begin{tabular}{|c|c|c|}
\hline Рік & Кількість & \% \\
\hline 1998 & 5 & 1,2 \\
\hline 1999 & 6 & 1,5 \\
\hline 2000 & 28 & 6,9 \\
\hline 2001 & 25 & 6,1 \\
\hline 2002 & 22 & 5,4 \\
\hline 2003 & 20 & 4,9 \\
\hline 2004 & 21 & 5,1 \\
\hline 2005 & 17 & 4,1 \\
\hline 2006 & 34 & 8,3 \\
\hline 2007 & 28 & 6,9 \\
\hline 2008 & 46 & 11,3 \\
\hline 2009 & 37 & 9,1 \\
\hline 2010 & 38 & 9,3 \\
\hline
\end{tabular}




\begin{tabular}{|c|c|c|}
\hline 2011 & 48 & 11,8 \\
\hline 2012 & 33 & 8,1 \\
\hline Всього & $\mathbf{4 0 8}$ & $\mathbf{1 0 0}$ \\
\hline
\end{tabular}

Типовидовий розподіл 408 видань за цільовим призначенням [8] виявив 313 науково-дослідних видань, 3 них монографій - 46, авторефератів дисертацій - 245, матеріалів науково-практичних i міжнародних науково-практичних конференцій i семінарів - 13, збірників наукових праць - 9; 5 науково-популярних видань; 45 науково-виробничих видань, 3 них - науково-методичних посібників - 40, методичних рекомендацій - 3, бібліотечок керівника дошкільного навчального закладу - 1 , інформаційно-методичних матеріалів - 1; 42 навчальні видання, 3 них - текстів лекцій 2, підручників, навчальних видань - 6, навчальних посібників - 31, програм, програмно-методичних комплексів - 3; 1 довідкове видання (термінологічний словник); 2 інформаційні видання (науково-допоміжні бібліографічні покажчики).

Отже, у РБД «Україніка наукова» найбільше складено рефератів на автореферати дисертацій, науково-методичні і навчальні посібники.

Акцентуємо увагу на аналізі відображення в загальнодержавній РБД «Україніка наукова» рефератів на науково-дослідні видання, зокрема монографії й автореферати дисертацій на здобуття наукових звань кандидата і доктора наук з питань дошкільної освіти і виховання, позаяк вони найкраще розкривають стан наукових досліджень 3 означеного питання.

Статистичний розподіл 46 монографій за роками вказує на стабільно більше їхнє відображення в РБД за останні п'ять років (2008-2012 pp.), а саме: 2008 р. - 6, 2009 р. 9, 2010 p. - 7, 2011 p. - 5, 2012 р. - 5. (табл. 2), коли, як уже зазначалося вище, активізувалось питання реформування дошкільної освіти і виховання.

Таблиия 2

\section{Динаміка відображення монографій в РБД «Україніка наукова» за 1998-2012 рр.}

\begin{tabular}{|c|c|}
\hline Рік & Кількість \\
\hline 1998 & - \\
\hline 1999 & - \\
\hline 2000 & - \\
\hline 2001 & - \\
\hline 2002 & 2 \\
\hline 2003 & - \\
\hline 2004 & 2 \\
\hline 2005 & 1 \\
\hline 2006 & 7 \\
\hline 2007 & 2 \\
\hline 2008 & 6 \\
\hline 2009 & 9 \\
\hline 2010 & 7 \\
\hline 2011 & 5 \\
\hline 2012 & 5 \\
\hline Всього & 46 \\
\hline
\end{tabular}

У ході аналізу було виокремлено 14 узагальнених тем, розкритих у монографіях: історія дошкільної педагогіки і дошкільного виховання (3 монографії); підготовка дошкільних працівників (10 монографій); організація дошкільного виховання (5 
монографій); теорія навчання, методична робота в дошкільному закладі, дошкільна установа, сім'я, громадськість (4 монографії); керівництво дошкільним закладом (1 монографія); вивчення мов, розвиток мови (10 монографій); розвиток математичних уявлень (1 монографія); виховання гуманізму (2 монографіï); виховання волі i характеру (1 монографія); виховання любові до природи (1 монографія); фізичне виховання (1 монографія); соціальне виховання учнів (2 монографії); естетичне виховання (3 монографії); рухливі ігри з правилами (2 монографії)

Наведені дані вказують на те, що найбільше відображено в РБД «Україніка наукова» монографій $з$ тем, які розкривають такі результати дослідження, а саме: проблеми підготовки дошкільних працівників і питання вивчення мов, розвитку мови, а найменше - 3 різноаспектних питань дошкільного виховання, зокрема 3 таких тем, як моральне виховання, виховання любові до природи, фізичне виховання тощо.

Географія означеної реферативної інформації розповсюджується на 19 наукових установ і вищих навчальних закладів (ВН3) України. Серед них найбільше складено рефератів на монографії Південного наукового центру НАПН України (6 рефератів), Бердянського педагогічного університету (5 рефератів), Запорізького інституту післядипломної педагогічної освіти (6 рефератів). Прореферовано по три монографії Київського університету ім. Б. Грінченка, Національного педагогічного університету ім. М. П. Драгоманова (НПУ ім. М. П. Драгоманова), Уманського державного педагогічного університету ім. П. Тичини, по дві - Інституту проблем виховання НАПН України, ДЗ «Південноукраїнський державний педагогічний університет ім. К. Д. Ушинського» (ДЗ «ПНПУ ім. К. Д. Ушинського”) та Рівненського державного гуманітарного університету. У решти встановлених під час дослідження ВНЗ України в РБД «Україніка наукова» відображено по одній монографії (табл. 3).

Таблиия 3

\section{Статистичний розподіл монографій за науковими установами і ВНЗ України, відображеними в РБД «Україніка наукова» за 1998-2012 рр.}

\begin{tabular}{|c|l|c|}
\hline $\begin{array}{c}\text { № } \\
\text { п/п }\end{array}$ & \multicolumn{1}{|c|}{ Назва організації } & Кількість \\
\hline 1 & Прикарпатський національний університет ім. В. Стефаника & 1 \\
\hline 2 & (без назви організації) & 5 \\
\hline 3 & Київський університет ім. Б. Грінченка, педагогічний інститут & 3 \\
\hline 4 & Хмельницький гуманітарно-педагогічний інститут & 1 \\
\hline 5 & $\begin{array}{l}\text { Національний педагогічний університет } \\
\text { ім. М. П. Драгоманова, інститут педагогіки і психології, } \\
\text { інститут розвитку дитини }\end{array}$ & 3 \\
\hline 6 & $\begin{array}{l}\text { Державний заклад «Південноукраїнський державний } \\
\text { педагогічний університет ім. К. Д. Ушинського» }\end{array}$ & 2 \\
\hline 7 & $\begin{array}{l}\text { Уманський державний педагогічний університет } \\
\text { ім. П. Тичини }\end{array}$ & 3 \\
\hline 8 & Південний науковий центр НАПН України & 1 \\
\hline 9 & $\begin{array}{l}\text { Глухівський національний педагогічний університет } \\
\text { ім. О. Довженка }\end{array}$ & 6 \\
\hline 10 & Запоріз. обл. ін-т післядиплом. освіти & 5 \\
\hline 11 & Бердянський державний педагогічний університет & 1 \\
\hline 12 & Луганський національний університет ім. Т. Шевченка & 1 \\
\hline 13 & Державний вищий навчальний заклад «Переяслав- & \multicolumn{1}{|c|}{} \\
\hline
\end{tabular}




\begin{tabular}{|c|l|c|}
\hline & $\begin{array}{l}\text { Хмельницький державний педагогічний університет } \\
\text { ім. Г. Сковороди» }\end{array}$ & 1 \\
\hline 14 & Кримський гуманітарний університет & 1 \\
\hline 15 & $\begin{array}{l}\text { Миколаївський державний університет } \\
\text { ім. В. О. Сухомлинського }\end{array}$ & 2 \\
\hline 16 & Рівненський державний гуманітарний університет & 2 \\
\hline 17 & Інститут проблем виховання НАПН України & 1 \\
\hline 18 & $\begin{array}{l}\text { Державний вищий навчальний заклад «Запорізький } \\
\text { національний університет» }\end{array}$ & 1 \\
\hline 19 & Волинський національний університет ім. Лесі Українки & $\mathbf{4 6}$ \\
\hline & Всього & \\
\hline
\end{tabular}

Аналіз реферативної інформації щодо авторефератів дисертацій на здобуття наукових звань кандидата і доктора наук з питань дошкільної освіти і виховання виявив такий їх статистичний розподіл за 16 спеціальностями [9], за якими проводився захист дисертацій (табл. 4):

Таблиия 4

\section{Статистичний розподіл авторефератів дисертацій за спеціальностями, за якими} проводиться захист дисертацій, відображених в РБД «Україніка наукова» 3а 1998-2012 pp.

\begin{tabular}{|c|c|}
\hline Код спеціальності & Кількість \\
\hline 13.00 .01 & 16 \\
\hline 13.00 .02 & 28 \\
\hline 13.00 .03 & 28 \\
\hline 13.00 .04 & 36 \\
\hline 13.00 .05 & 1 \\
\hline 13.00 .06 & 3 \\
\hline 13.00 .07 & 26 \\
\hline 13.00 .08 & 61 \\
\hline 13.00 .09 & 2 \\
\hline 14.02 .01 & 1 \\
\hline 19.00 .03 & 1 \\
\hline 19.00 .05 & 2 \\
\hline 19.00 .07 & 25 \\
\hline 19.00 .08 & 2 \\
\hline 24.00 .02 & 10 \\
\hline 24.00 .03 & $\mathbf{2 4 5}$ \\
\hline Всього & \\
\hline
\end{tabular}

1) 13 Педагогічні науки - всього 201 автореферат дисертації, а саме: 13.00.01 Загальна педагогіка та історія педагогіки - 16; 13.00.02. Теорія та методика навчання (з галузей знань) - 28; 13.00 .03 Корекційна педагогіка - 28; 13.00 .04 Теорія і методика професійної освіти - 36; 13.00.05 Соціальна педагогіка - 1; 13.00.06 Теорія і методика управління освітою - 3; 13.00.07 Теорія і методика виховання - 26; 13.00.08 Дошкільна педагогіка - 61; 13.00.09 Теорія навчання 2 ; 
2) 14.02.00 Профілактична медицина - усього 1 автореферат дисертації, а саме: 14.02.01 Гігієна та професійна патологія - 1;

3) 19 Психологічні науки - усього 30 авторефератів дисертацій, а саме: 19.00.03 Психологія праці; інженерна психологія - 1; 19.00.05 Соціальна психологія; психологія соціальної роботи - 2; 19.00.07 Педагогічна та вікова психологія 25; 19.00.08 Спеціальна психологія - 2;

4) 24 Фізичне виховання та спорт - усього 13 авторефератів дисертацій, а саме: 24.00.02 Фізична культура, фізичне виховання різних груп населення - 10; 24.00.03 Фізична реабілітація - 3.

Iз наведених статистичних даних видно, що найбільша кількість авторефератів дисертацій, відображених у РБД «Україніка наукова», виявлена зі спеціальностей 13.00.08 Дошкільна педагогіка - 61, 13.00.04 Теорія і методика професійної освіти - 36, 13.00.02. Теорія та методика навчання (з галузей знань) - 28; 13.00 .03 Корекційна педагогіка - 28, 13.00.07 Теорія і методика виховання - 26, 19.00.07 Педагогічна та вікова психологія - 25. Зокрема, за спеціальністю 13.00 .08 найбільша кількість дисертацій захищалася за такими темами як: виховання дітей дошкільного віку різних вікових категорій (5), ознайомлення з навколишнім життям і природою (5), естетичне виховання (7), підготовка дітей дошкільного віку до школи, дитячий заклад і школа (5), Історія дошкільної педагогіки і дошкільного виховання (4). Складено реферати на два автореферати дисертацій з тем: завідувач дитячого закладу, організація дошкільного виховання, дошкільна установа і сім'я тощо. Встановлено, що з таких тем як фізичне виховання, виховання гуманізму, виховання безпечної поведінки в соціальному середовищі, види дитячих ігор, методична робота в дошкільному закладі, колектив дошкільної установи та інших прореферовано по одному автореферату.

В авторефератах дисертацій зі спеціальності 19.00.07 найчастіше розкриваються теми, серед яких: здібності й обдарованість дітей дошкільного віку (4), психологія дитячої творчості (3), психологія виховання дітей дошкільного віку (3), формування особистості дитини цього віку (3), вивчення мов, розвиток мови (3). Дошкільній сурдопедагогіці, психології розумово відсталих дітей в цілому присвячено 3 автореферати дисертацій. Найменше розкрито теми,що стосуються психології навчання дітей дошкільного віку, психологія гри, розумове виховання, психологічні проблеми соціального спілкування тощо.

Отже, РБД «Україніка наукова» відображає реферативну інформацію щодо авторефератів дисертацій 3 питань дошкільної освіти і виховання не тільки 3 педагогічної і психологічної галузі, а й профілактичної медицини і фізичного виховання і спорту.

Кількісні показники розподілу за спеціальностями, за якими проводився захист дисертацій, виявив лакуни у розробці наукових тем або недостатнє розкриття їх аспектів. Так, зовсім не виявлено авторефератів дисертацій із спеціальності 13.00.10 Інформаційно-комунікаційні технології в освіті, хоча на сьогодні знайомство дітей 3 комп'ютером відбувається уже в дошкільному віці.

Тематика авторефератів дисертацій найбільше присвячена загальним питанням виховання дітей дошкільного віку різних вікових категорій та окремим його видам, як то: естетичне виховання, ознайомлення з навколишнім життям і природою, фізичне виховання.

Статистичний розподіл авторефератів дисертацій за досліджуваний період (15 років) виявив таку картину їх реферування в РБД (табл. 5). 
Таблиия 5

Динаміка відображення авторефератів дисертацій в РБД «Україніка наукова» 3a 1998-2012 pp.

\begin{tabular}{|c|c|c|}
\hline Рік & Кількість & \% \\
\hline 1998 & 2 & 0,8 \\
\hline 1999 & 2 & 0,8 \\
\hline 2000 & 21 & 8,6 \\
\hline 2001 & 17 & 6,9 \\
\hline 2002 & 13 & 5,3 \\
\hline 2003 & 15 & 6,1 \\
\hline 2004 & 15 & 6,1 \\
\hline 2005 & 13 & 5,3 \\
\hline 2006 & 17 & 6,9 \\
\hline 2007 & 20 & 8,2 \\
\hline 2008 & 22 & 9,0 \\
\hline 2009 & 21 & 8,6 \\
\hline 2010 & 16 & 6,5 \\
\hline 2011 & 31 & 12,7 \\
\hline 2012 & 20 & 8,2 \\
\hline Всього & $\mathbf{2 4 5}$ & $\mathbf{1 0 0}$ \\
\hline
\end{tabular}

3'ясовано,що за вказані роки від 13 до 17 авторефератів дисертацій було прореферовано в РБД з означеної теми в 2002-2006 роках і в 2010 році, а 20-22 авторефератів дисертацій - у 2000 році, у 2007-2009 роках, у 2011 році і в 2012 році. Найбільша їх кількість відображена в РБД у 2011 році - 31 (12,6 \%) автореферат дисертацій від загальної кількості цього виду наукових публікацій (245 авторефератів дисертацій). Кількісно 31 автореферат дисертацій можна розподілити за такими 9 узагальненими темами, як: історія дошкільної педагогіки і дошкільного виховання, історія вищої педагогічної освіти в Україні (3); підготовка дошкільних працівників, система підвищення кваліфікації педагогів в Україні (5); вивчення мов, розвиток мови (3); виховання навичок культурної поведінки, виховання поваги до старших, моральне виховання, виховання колективізму, дружби, товариськості (4); дошкільна установа i сім'я, виховання дітей з урахуванням віку (4); фізичне виховання дошкільників (2); виховання і навчання дітей дошкільного віку з вадами психофізичного розвитку (5); естетичне виховання дошкільників (4); статеве виховання дошкільників (1).

У цьому році географія захисту дисертацій 3 питань дошкільної освіти i виховання розповсюдилася на 14 вищих навчальних закладів і наукових установ України, а саме: на Уманський державний педагогічний університет ім. П. Тичини (1), Київський університет ім. Б. Грінченка (1), Кримський гуманітарний університет (1), НПУ ім. М. П. Драгоманова (5), Харківський національний педагогічний університет ім. Г. С. Сковороди (2), ДЗ «ПНПУ ім. К. Д. Ушинського» (9), Волинський національний університет ім. Лесі Українки (1), Прикарпатський національний університет ім. В. Стефаника (2), Дніпропетровський державний інститут фізичної культури і спорту (1), Харківську державну академію фізичної культури (1); установи НАПН України (м. Київ): Інститут психології ім. Г. С. Костюка НАПН України (3), Університет менеджменту освіти НАПН України (1), Інститут спеціальної педагогіки НАПН України (1), Інститут проблем виховання НАПН України (2). 
Зокрема, слід зазначити, що 3 найбільшої кількості - дев'яти авторефератів дисертацій ДЗ «ПНПУ ім. К. Д. Ушинського», відображених в РБД «Україніка наукова», сім відносяться до спеціальності 13.00.08 Дошкільна педагогіка на здобуття наукового звання кандидата наук [теми: підготовка дошкільних працівників, виховання навиків культурної поведінки (2), дошкільна установа і сім'я, статеве виховання дітей старшої групи дитячого садка (6 років) (3), естетичне виховання (2)], а два до 13.00.01 Загальна педагогіка та історія педагогіки (тема: історія дошкільної педагогіки і дошкільного вихованн) та 13.00.02 Теорія і методика навчання (з галузей знань) (тема: українська мова,вивчення мов, розвиток мови) на здобуття наукового звання доктора наук.

3 п'яти авторефератів дисертацій на здобуття звання кандидата наук в НПУ ім. М. П. Драгоманова, три відносяться до спеціальності 13.00.03 Корекційна педагогіка (теми: формування образного мовлення у дітей старшого дошкільного віку із загальним недорозвиненням мовлення; дошкільна тифлопедагогіка, українська мова; формування емоційно-оцінної лексики у дітей старшого дошкільного віку з моторною алалією засобами художньо-мовленнєвої діяльності), а два відповідно до 13.00.01 Загальна педагогіка та історія педагогіки (тема: історія дошкільної педагогіки і дошкільного виховання) і 13.00.02 Теорія і методика навчання (з галузей знань) (тема: естетичне виховання засобами музичного мистецтва). До згаданих вище авторефератів дисертацій на здобуття наукового звання доктора наук у 2011 році слід віднести також один автореферат дисертації за спеціальністю 19.00.07 Педагогічна та вікова психологія Інституту психології ім. Г. С. Костюка НАПН України.

Отже, варто зауважити, що за останні роки простежується тенденція майже однакової щорічної кількості авторефератів дисертацій з питань дошкільної освіти і виховання, які відображувано у РБД «Україніка наукова». 2011 рік є винятком, який можна пов'язати ще й $з$ активізацією захисту дисертацій у таких вищих навчальних закладах, як ДЗ «ПНПУ ім. К. Д. Ушинського» і НПУ ім. М. П. Драгоманова. Слід зазначити також, що серед ВНЗ педагогічного спрямування ці заклади є лідерами у захисті дисертацій на досліджувану тему. Так, із 245 авторефератів дисертацій, виявлених у БД «Україніка наукова» $з$ питань дошкільної освіти та виховання, ДЗ «ПНПУ ім. К. Д. Ушинського» належить 52 автореферати дисертацій, а НПУ ім. М. П. Драгоманова - 34 автореферати дисертацій (табл. 6).

Таблиия 6

Статистичний розподіл авторефератів дисертацій за науковими установами і ВНЗ України, відображеними в РБД «Україніка наукова» за 1998-2012 рр.

\begin{tabular}{|c|l|c|}
\hline $\begin{array}{c}\text { No } \\
\text { п/п }\end{array}$ & \multicolumn{1}{|c|}{ Назва організації } & К-сть автореф. дис. \\
\hline 1 & Інститут педагогіки НАПН України & 6 \\
\hline 2 & Інститут проблем виховання НАПН України. & 43 \\
\hline 3 & Інститут психології ім. Г. С. Костюка НАПН України & 15 \\
\hline 4 & Інститут спеціальної педагогіки НАПН України & 18 \\
\hline 5 & Інститут вищої освіти НАПН України & 2 \\
\hline 6 & $\begin{array}{l}\text { Інститут педагогічної освіти і освіти дорослих НАПН } \\
\text { України }\end{array}$ & 2 \\
\hline 7 & $\begin{array}{l}\text { Інститут педагогіки і психології професійної освіти } \\
\text { НАПН України. }\end{array}$ & 3 \\
\hline 8 & Університет менеджменту освіти НАПН України, & 34 \\
\hline 9 & $\begin{array}{l}\text { Національний педагогічний університет } \\
\text { ім. М. П. Драгоманова }\end{array}$ & 2 \\
\hline
\end{tabular}




\begin{tabular}{|c|c|c|}
\hline 10 & $\begin{array}{l}\text { Державний заклад «Південноукраїнський національний } \\
\text { педагогічний університет ім. К. Д. Ушинського» }\end{array}$ & 52 \\
\hline 11 & $\begin{array}{l}\text { Уманський державний педагогічний університет } \\
\text { iм. П. Тичини }\end{array}$ & 2 \\
\hline 12 & $\begin{array}{l}\text { Державний вищий навчальний заклад } \\
\text { «Прикарпатський національний університет ім. } \\
\text { В. Стефаника» }\end{array}$ & 6 \\
\hline 13 & $\begin{array}{l}\text { Харківський національний університет } \\
\text { ім. В. Н. Каразіна }\end{array}$ & 1 \\
\hline 14 & $\begin{array}{l}\text { Східноукраїнський національний університет } \\
\text { ім. В. Даля }\end{array}$ & 1 \\
\hline 15 & Київський університет ім. Б. Грінченка & 4 \\
\hline 16 & $\begin{array}{l}\text { Луганський національний педагогічний університет } \\
\text { iм. Т. Шевченка }\end{array}$ & 9 \\
\hline 17 & $\begin{array}{l}\text { Вінницький державний педагогічний університет } \\
\text { iм. М. Коцюбинського }\end{array}$ & 1 \\
\hline 18 & $\begin{array}{l}\text { Миколаївський державний університет } \\
\text { iм. В. О. Сухомлинського }\end{array}$ & 1 \\
\hline 19 & $\begin{array}{l}\text { Тернопільський національний педагогічний } \\
\text { університет ім. В. Гнатюка }\end{array}$ & 2 \\
\hline 20 & Харківська державна академія фізичної культури & 3 \\
\hline 21 & $\begin{array}{l}\text { Харківський національний педагогічний університет } \\
\text { ім. Г. С. Сковороди }\end{array}$ & 12 \\
\hline 22 & Рівненський державний гуманітарний університет & 2 \\
\hline 23 & $\begin{array}{l}\text { Державна установа «Інститут гігієни та медичної } \\
\text { екології ім. О. М. Марзєєва АМН України» }\end{array}$ & 1 \\
\hline 24 & $\begin{array}{l}\text { Сумський державний педагогічний університет } \\
\text { iм. А. С. Макаренка }\end{array}$ & 1 \\
\hline 25 & $\begin{array}{l}\text { Республіканський вищий навчальний заклад } \\
\text { «Кримський гуманітарний університет» (м. Ялта) }\end{array}$ & 4 \\
\hline 26 & Волинський національний університет ім. Л. Українки & 2 \\
\hline 27 & Класичний приватний університет (Запоріжжя) & 1 \\
\hline 28 & Львівський державний університет фізичної культури & 4 \\
\hline 29 & $\begin{array}{l}\text { Черкаський національний університет } \\
\text { ім. Б. Хмельницького }\end{array}$ & 1 \\
\hline 30 & Херсонський державний університет & 1 \\
\hline 31 & Одеський національний університет ім. І. І. Мечникова & 1 \\
\hline 32 & $\begin{array}{l}\text { Національний університет фізичного виховання і } \\
\text { спорту України }\end{array}$ & 2 \\
\hline 33 & Криворізький державний педагогічний університет & 2 \\
\hline 34 & $\begin{array}{l}\text { Дрогобицький державний педагогічний університет } \\
\text { iм. І. Франка }\end{array}$ & 1 \\
\hline \multirow[t]{2}{*}{35} & $\begin{array}{l}\text { Дніпропетровський державний інститут фізичної } \\
\text { культури і спорту }\end{array}$ & 1 \\
\hline & ВСБОГО & 245 \\
\hline
\end{tabular}

У РБД «Україніка наукова» за досліджуваний період із 245 авторефератів дисертацій 35 наукових установ і закладів України відображено 93 (38 \%) автореферати дисертацій 8 наукових установ НАПН України: Інституту педагогіки НАПН України, 
Інституту проблем виховання НАПН України, Інституту психології ім. Г. С. Костюка НАПН України, Інституту спеціальної педагогіки НАПН України, Інституту вищої освіти НАПН України, Інституту педагогічної освіти і освіти дорослих НАПН України, Інституту педагогіки і психології професійної освіти НАПН України, Університету менеджменту освіти НАПН України, серед яких найбільшу кількість було захищено в Інституті проблем виховання НАПН України (43), Інституті спеціальної педагогіки НАПН України (18) та Інституті психології ім. Г. С. Костюка НАПН України (15) (табл. 6).

Зокрема, 43 автореферати дисертацій Інституту проблем виховання НАПН України класифікуються за 5 спеціальностями: 13.00.01 Загальна педагогіка та історія педагогіки (1), 13.00.02 Теорія та методика навчання (з галузей знань) (3), 13.00.07 Теорія і методика виховання (11), 13.00.08 Дошкільна педагогіка (27), 13.00.09 Теорія навчання (1). Найбільше авторефератів дисертацій відображено 3 естетичного виховання (8), фізичного виховання (5), розвитку математичних уявлень (4), ознайомлення з природою (3), етнопедагогіки (2) тощо. Автореферати дисертацій Інституту спеціальної педагогіки НАПН України представлено найбільше із спеціальності 13.00 .03 (13). Три автореферати дисертацій виявлено із спеціальності 19.00.07 Педагогічна та вікова психологія та дві із 19.00.08 Спеціальна психологія. Автореферати дисертацій Інституту психології ім. Г. С. Костюка НАПН України в РБД «Україніка наукова» представлено із спеціальностей 13.00.02 Теорія та методика навчання (з галузей знань) (1), 13.00.08 Дошкільна педагогіка (2), 19.00.03 Психологія праці; інженерна психологія (1), 19.00.05 Соціальна психологія; психологія соціальної роботи (2), 19.00.07 Педагогічна та вікова психологія (9).

Отже, означені наукові установи НАПН України, для яких досліджувана тема $€$ близькою до основних напрямів їх наукової діяльності, активно розробляють педагогічні і психологічні проблеми дошкільної освіти і виховання.

За період з 1998 по 2012 рік включно з питань дошкільної освіти і виховання в РБД «Україніка наукова» відображено 18 авторефератів дисертацій на здобуття звання доктора наук: 2001 р. -- 3, 2002 p. - 3, 2003p. - 1, 2004 p. - 2, 2006 p. - 1, 2007 p. - 1, 2009 p. $-2,2011$ p. $-3,2012$ p. -2.

У 1998-2000 pp., 2005 р., 2008 р., 2010 р. - докторські дисертації з вказаної теми не захищалися. Шість авторефератів дисертацій на здобуття звання доктора педагогічних та психологічних наук відносяться до наукових установ НАПН України, а саме: Інституту педагогіки НАПН України (1), Інституту проблем виховання НАПН України (1), Інституту педагогічної освіти і освіти дорослих НАПН України (2), Інституту психології ім. Г. С. Костюка НАПН України (2). Авторами їх є такі відомі вчені як: Г. О. Підкурганна, Г. В. Бєлєнька, Л. О. Калмикова, О. Л. Кононко, Т. М. Шкваріна, О. Г. Кучерявий. Серед вищих навчальних закладів знову займають першість ДЗ «ПНПУ ім. К. Д. Ушинського» і НПУ ім. М. П. Драгоманова - по 4 автореферати дисертацій відповідно таких науковців як: Т. М. Степанової, Н. В. Горбунової, Н. І. Луцан, Т. Г. Жаровцевої, Н. В. Гавриш, Н. Ф. Денисенко, I. Адамек, Б. Мухацької. Харківський національний педагогічний університет ім. Г. С. Сковороди представлений авторефератами дисертацій вчених Т. П. Танько та Н. Г. Грами; Луганський національний університет ім. Т. Шевченка - І. П. Рогальської. У РБД розміщено також автореферат дисертації на здобуття звання доктора медичних наук О. П. Івахно (Держ. установа «Інститут гігієни та медичної екології ім. О. М. Марзєєва НАМН України») 3 теми «Гігієна дітей дошкільного віку. Фізичне виховання».

Вище зазначені статистичні дані вказують на те, що в РБД «Україніка наукова» в темі дошкілля за 15 років виявлено всього 7,3\% авторефератів дисертацій на здобуття 
звання доктора наук. В основному тематика означених авторефератів дисертацій зосереджена на історії дошкільної педагогіки і дошкільного виховання, підготовці дошкільних працівників, вивченні мов та розвитку мови.

\section{3. ВИСНОВКИ ТА ПЕРСПЕКТИВИ ПОДАЛЬШИХ ДОСЛІДЖЕНЬ}

Таким чином, можна зробити висновок про те, що за досліджуваний період активізація наукових досліджень 3 питань дошкільної освіти і виховання відбувалася протягом останніх п’яти років (2008-2012рр.). Темпи здійснення досліджень в ці роки знаходяться майже на одному рівні, зростаючи в певний період, що залежить від збільшення кількості досліджень у деяких установах і навчальних закладах, і викликів суспільства, що знайшло своє відображення в РБД «Україніка наукова». За допомогою бібліометричного методу виявлено реферативну інформацію не тільки щодо найбільш активно досліджуваних тем і лакун в цій сфері та інтенсивності їх відображення в окремі роки, а й організації, які є лідерами у науковій діяльності з актуальних питань розвитку дошкільної освіти і виховання.

Слід зазначити, що незначна кількість виявлених рефератів на монографії $(11,3$ \%) не дала можливості повноцінно відстежити тематику досліджень 3 питань дошкільної освіти і виховання, й організації, які їх проводять. Це, зокрема стосується досліджень 3 питань виховання дошкільнят, на яку мало виявлено рефератів на монографії, але знайдено значну кількість рефератів на автореферати дисертацій. Статистичні дані щодо відображення в РБД «Україніка наукова» авторефератів дисертацій зі спеціальностей 13.00.07 Теорія і методика виховання, 13.00.08 Дошкільна педагогіка, а також тих, що відносяться до установ НАПН України, зокрема Інституту проблем виховання НАПН України, підтверджують широкий спектр авторефератів дисертацій 3 питань дошкільного виховання й інтенсивність означених досліджень, зокрема з питань теорії і методики виховання, естетичного, фізичного виховання, виховання любові до природи.

Значна частина досліджень, особливо у ВНЗ України, присвячена темам підготовки дошкільних працівників, вивченню мов та розвитку мови, історії дошкільної освіти та виховання.

РБД «Україніка наукова» дає змогу користувачу проводити пошук інформації в її власних ресурсах і друкованих тематичних серіях УРЖ «Джерело», прогнозувати розвиток наукового знання в Україні, а постійне оновлення РБД реферативною інформацією $є$ одним $з$ ефективних засобів інформаційного забезпечення наукових досліджень.

Реферування наукових видань із питань педагогіки, психології і освіти є одним із провідних напрямів діяльності ДНПБ України ім. В. О. Сухомлинського. 32007 року бібліотека як науково-дослідна установа i головний науково-методичний i координаційний центр мережі освітянських бібліотек МОН України та НАПН України у своїх наукових проектах розробляє теоретичні, науково-методичні та організаційні засади системи реферативного забезпечення педагогічної науки й освіти, активно втілюючи в практику наукові розробки, інноваційні методи роботи, тим самим стимулюючи дії бібліотек мережі на активізацію й модернізацію процесів їх діяльності щодо забезпечення принципів рівного доступу до інформаційно-бібліотечних ресурсів і навчання громадян України протягом усього життя. Участь у проекті НБУВ щодо формування загальнодержавної РБД «Україніка наукова», а також створення галузевої РБД на порталі ДНПБ України ім. В. О. Сухомлинського сприяє сьогодні більш повноцінному і якісному інформаційному забезпеченню фахових потреб освітян. 
Вбачається доцільним проводити активну популяризацію достатньо потужного масиву реферативних інформаційних ресурсів НБУВ з метою відображення в них усіх видань, що випускають наукові організації з питань дошкільної освіти і виховання, їх подальшого активного використання вітчизняними вченими-педагогами для розв'язання нагальних проблем у цій галузі.

Подальші дослідження будуть присвячені бібліометричним аналізам відображення реферативної інформації в РБД «Україніка наукова» щодо інших рівнів освіти, зокрема загальної середньої освіти.

\section{СПИСОК ВИКОРИСТАНИХ ДЖЕРЕЛ}

1. Біла книга національної освіти України / НАПН України ; за заг. ред. В. Г. Кременя ; [Т. Ф. Алексєєнко, В. М. Аніщенко, Г. О. Балл та ін.]. - К. : Інформ. системи, 2010. - 342 с. Бібліогр.: с. 315-335.

2. Бережняк, О. В. Бібліометрія як метод аналізу стану книговидання [Електронний ресурс] / Олена Володимирівна Бережняк // Адаптація завдань і функцій наукової бібліотеки до вимог розвитку цифрових інформаційних ресурсів : Міжнар. наук. конф., 8-10 жовт. 2013 р., Київ : тези доп. / Нац. б-ка України ім. В. І. Вернадського. - Електрон. дані. - К., 2013. - Режим доступу : http://conference.nbuv.gov.ua/report/view/id/230. - Назва з екрана.

3. Добровська, С. „Інформаційні технології” у реферативній базі даних „Україніка наукова” / С. Добровська, С. Кириленко, І. Балагура // Бібл. вісн. - 2012. - № 4. - С. 12-17.

4. Зайченко, Н. Я. Бібліометрика у РБД „Україніка наукова” [Електронний ресурс] / Надія Яківна Зайченко // Адаптація завдань і функцій наукової бібліотеки до вимог розвитку цифрових інформаційних ресурсів : Міжнар. наук. конф., 8-10 жовт. 2013 р., Київ : тези доп. / Нац. б-ка України ім. В. І. Вернадського. - Електрон. дані. - К., 2013. - Режим доступу : http://conference.nbuv.gov.ua/report/view/id/168. - Назва з екрана.

5. Заліток, Л. Бібліометричне дослідження матеріалів про В. О. Сухомлинського в загальнодержавній реферативній базі даних „Україніка наукова” / Людмила Заліток // Наук. записки. Сер.: Пед. науки / МОН України, Кіровогр. держ. пед. ун-т ім. В. Винниченка. - Кіровоград, 2013. - Вип. 123, т. 1. C. $160-164$.

6. Кремень, В. Василь Кремень: На часі наукове осмислення інноваційної педагогічної освіти та тї впровадження [Електронний ресурс] : [розмова 3 президентом НАПН України Василем Григоровичем Кременем про актуальні результати діяльності відділень найголовнішої освітянської наукової установи та плани на майбутнє / записала Олена Солодовнік] // ПедПреса : освітній портал. - Електрон дані. - К., 2013. - Режим доступу : http://pedpresa.com.ua/blog/vasylkremen-na-chasi-naukove-osmyslennya-innovatsijnoji-pedahohichnoji-osvity-ta-jiji-

vprovadzhennya.html. - Назва з екрана.

7. Кремень, В. Г. Виступ президента НАПН України В. Г. Кременя на засіданні колегії Міністерства освіти і науки України 27 серпня 2013 року [Електронний ресурс] / В. Г. Кремень // Національна академія педагогічних наук України : [офіц. веб-сайт]. - Електрон. дані. - К., 2013. - Режим доступу : http://naps.gov.ua/ua/press/releases/203/. - Назва з екрана.

8. Кушнаренко, Н. Н. Документоведение : учебник / Н. Н. Кушнаренко. - 8-е изд., стер. - К., 2008. С. 171-218. - (Высшее образование XXI века).

9. Про затвердження Переліку наукових спеціальностей [Електронний ресурс] : (із змінами, внесеними згідно з Наказом Міністерства освіти і науки, молоді та спорту № 1462 від 21.12.2012) : наказ М-ва освіти і науки, молоді та спорту України від 14.09.2011 № 1057 // Верховна Рада України : [офіц. веб-портал]. - Електрон. дані. - К., 2011. - Режим доступу : http://zakon4.rada.gov.ua/laws/show/z1133-11/page. - Назва з екрана.

10. Сандул, О. Г. Бібліометричний аналіз наукових публікацій з проблем розвитку вітчизняної енергетики (на основі реферативних ресурсів НБУВ) [Електронний ресурс] / Оксана Георгіївна Сандул // Адаптація завдань i функцій наукової бібліотеки до вимог розвитку цифрових інформаційних ресурсів : Міжнар. наук. конф., 8-10 жовт. 2013 р., Київ : тези доп. / Нац. б-ка України ім. В. І. Вернадського. - Електрон. дані. - К., 2013. - Режим доступу : http://conference.nbuv.gov.ua/report/view/id/70. - Назва 3 екрана.

11. Табачник, Д. В. Виступ Міністра освіти і науки України Табачника Дмитра Володимировича на загальних зборах НАПН України 4 квітня 2013 року [Електронний ресурс] / Дмитро 
Володимирович Табачник // Міністерство освіти і науки України : офіц. веб-сайт. - Електрон. дані. - К., 2013. - Режим доступу: http://www.mon.gov.ua/about-ministry/47/113/. - Назва з екрана.

\title{
БИБЛИОМЕТРИЧЕСКИЙ АНАЛИЗ НАУЧНЫХ ПУБЛИКАЦИЙ ПО ВОПРОСАМ ДОШКОЛЬНОГО ОБРАЗОВАНИЯ И ВОСПИТАНИЯ В ОБЩЕГОСУДАРСТВЕННОЙ РЕФЕРАТИВНОЙ БД „УКРАИНИКА НАУЧНАЯ” (1998-2012 гг.)
}

\author{
Букшина Тамара Федотовна \\ научный сотрудник \\ Государственная научно-педагогическая библиотека Украины имени В. А. Сухомлинского, г. Киев, \\ Украина \\ bukshina@i.ua
}

\begin{abstract}
Аннотация. Освещены результаты анализа потока научных публикаций по вопросам дошкольного образования и воспитания в общегосударственной реферативной БД «Украиника научная» за 1998-2012 годы с использованием библиометрического метода. Определены тенденции развития дошкольного образования и воспитания в этой базе данных. Выявлена реферативная информация, касающаяся не только наиболее активно изучаемых тем и пробелов в этой сфере, а также интенсивности ее отражения в отдельные годы, но и научных учреждений и высших учебных заведений, которые являются лидерами в научной деятельности по актуальным вопросам реформирования дошкольного образования и воспитания. Подчеркнута важность отображения результатов научных исследований в реферативной БД «Украиника научная».
\end{abstract}

Ключевые слова: дошкольное образование и воспитание; общегосударственная реферативная база данных «Украиника научная»; библиометрический анализ; монографии; авторефераты диссертаций; ГНПБ Украины им. В. А. Сухомлинского.

\section{BIBLIOMETRIC ANALYSIS OF SCIENTIFIC PUBLICATIONS ON PRESCHOOL EDUCATION AND TRAINING IN NATIONAL ABSRACTS DATABASE „UKRAINIKA SCIENTIFIC” (1998-2012)}

\author{
Tamara F. Bukshyna \\ researcher \\ V. Sukhomlynskyi State Scientific and Pedagogical Library of Ukraine, Kyiv, Ukraine \\ bukshina@i.ua
}

\begin{abstract}
In the article it is highlighted the results of analysis of flow of scientific publications on pre-school education and training in the national abstracts database «Ukrainika scientific» for the years 1998-2012 using bibliometric method. There are determined tendencies of the development of pre-school education and training in this database. It is found out an abstract information concerning not only the most actively studied topics and gaps in this area, as well as the intensity of its reflection in some years, but scientific institutions and universities which are leaders in scientific activities on topical issues of reform of preschool education. It is highlighted the importance of representation of research results in the national abstracts database «Ukrainika scientific».
\end{abstract}

Keywords: pre-school education and training; national abstracts database «Ukrainika scientific»; bibliometric analysis; monographs; thesis abstracts; V. A. Sukhomlinskyi State Scientific Pedagogical Library of Ukraine. 


\section{REFERENCES (TRANSLATED AND TRANSLITERATED)}

1. White Book of National Education of Ukraine / NAPN Ukrayiny ; according Society. eds. V. H. Kremenya ; [T. F. Aleksyeyenko, V. M. Anishchenko, H. O. Ball et al.]. - K. : Inform. systemy, 2010. - 342 c. - Ref.: c. 315-335. (in Ukrainian)

2. Berezhnyak, O.V. As a method of bibliometric analysis of the publishing [online] / Olena Volodymyrivna Berezhnyak // Adaptation objectives and functions of academic libraries with the requirements of digital information resources : Internat. sciences. conf., Oct. 8-10 2013, Kyiv : abstract add. / Nats. b-ka Ukrayiny im. V. I. Vernads'koho. - Email. data. - K., 2013. - Available from : http://conference.nbuv.gov.ua/report/view/id/230. - The name of the screen. (in Ukrainian)

3. Dobrovs'ka, S. «Information Technology» in a summary database «Ukrainika scientific» / S. Dobrovs'ka, S. Kyrylenko, I. Balahura // Bibliotechnyy visnyk. - 2012. - № 4. - S. 12-17. (in Ukrainian)

4. Zaychenko, N. Ya. Bibliometryka in RDB «Ukrainika scientific» [online] / Nadiya Yakivna Zaychenko // Adaptation objectives and functions of academic libraries with the requirements of digital information resources : Internat. sciences. conf., Oct. 8-10 2013, Kyiv : abstract add. / Nats. b-ka Ukrayiny im. V. I. Vernads'koho. - Email. data. - K., 2013. - Available from : http://conference.nbuv.gov.ua/report/view/id/168. - The name of the screen. (in Ukrainian)

5. Zalitok, L. Bibliometric study materials on Sukhomlinskiy a summary of the national database «Ukrainika scientific» / Lyudmyla Zalitok // Naukovi zapysky. Ser.: Ped. nauky / MON Ukrayiny, Kirovohr. derzh. ped. un-t im. V. Vynnychenka. - Kirovohrad, 2013. - Vyp. 123, t. 1. - S. 160-164. (in Ukrainian)

6. Kremen', V. Vasyl' Kremen': At the time the scientific understanding of innovative teacher education and its implementation [online]: [a conversation with the president of NAPS of Ukraine Vasyl Kremen G. on actual performance of the most important of all branches of educational research institutions and plans for the future /_Helen recorded Solodovnik] // PedPresa : osvitniy portal. - Electron data. - K., 2013. Available from : http://pedpresa.com.ua/blog/vasyl-kremen-na-chasi-naukove-osmyslennyainnovatsijnoji-pedahohichnoji-osvity-ta-jiji-vprovadzhennya.html. - The name of the screen. (in Ukrainian)

7. Kremen', V. H. Speech of President of NAPS of Ukraine V. Kremen at a meeting of the Ministry of Education and Science of Ukraine August 27, 2013 [online] / V. H. Kremen'// Natsional'na akademiya pedahohichnykh nauk Ukrayiny : [ofits. veb-sayt]. - Email. data. - K., 2013. - Available from : http://naps.gov.ua/ua/press/releases/203/. - The name of the screen. (in Ukrainian)

8. Kushnarenko, N. N. Dokumentovedenye: Tutorial / N. N. Kushnarenko. - 8th ed., Erased. - K., 2008. S. 171-218. - (Higher Education XXI century). (in Ukrainian)

9. On approval of academic majors [online] (as amended by Decree of the Ministry of Education, Youth and Sport № 1462 from 21.12.2012): order M islands of Education, Youth and Sports of Ukraine from 14.09.2011 number 1057 // Verkhovna Rada Ukrayiny : [ofits. veb-portal]. - Email. data. - K., 2011. Available from : http://zakon4.rada.gov.ua/laws/show/z1133-11/page. - The name of the screen. (in Ukrainian)

10. Sandul, O. H. Bibliometric analysis of scientific publications on the development of domestic energy (based on abstract resources Vernadsky National Library) [online] / Oksana Heorhiyivna Sandul // Adaptation objectives and functions of academic libraries with the requirements of digital information resources : Internat. sciences. conf., Oct. 8-10 2013, Kyiv : abstract add. / Nats. b-ka Ukrayiny im. V. I. Vernads'koho. - Email. data. - K., 2013. - Available from: http://conference.nbuv.gov.ua/report/view/id/70. - The name of the screen. (in Ukrainian)

11. Tabachnyk, D. Statement by the Minister of Education and Science of Ukraine Dmytro Tabachnik at the general meeting of NAPS Ukraine April 4, 2013 [online] / Dmytro Volodymyrovych Tabachnyk // Ministerstvo osvity i nauky Ukrayiny : ofits. veb-sayt.- Email. data. - K., 2013. - Available from : http://www.mon.gov.ua/about-ministry/47/113/. - The name of the screen. (in Ukrainian) 